\title{
Occupational exposure to home risk factors: analysis of physical and mental health condition of a group of Sicilian housewives
}

\author{
Maria Gabriella Verso \\ Diego Picciotto
}

Section of Occupational Medicine Institute, "G. D'Alessandro" Department of Science for Health Promotion and Maternal Childish, University of Palermo, Palermo, Italy

\section{Corresponding Author:}

Maria Gabriella Verso

Section of Occupational Medicine "G. D'Alessandro"

Department of Science for Health Promotion

and Maternal Childish, University of Palermo

Via del Vespro 143

90127 Palermo, Italy

E-mail: mariagabriella.verso@unipa.it

\begin{abstract}
Introduction: the work of housewives, in many ways, still lacks professional respect; particularly with respect to the neglect of exposure to risk factors such as: chemical, physical, biological, psychological and accidents. The purpose of this study is to analyze the possible impact of environmental risk factors on the physical and mental health of a group of Sicilian housewives.

Methods: we enrolled housewives living in Palermo and Catania and administered an anonymous questionnaire to obtain knowledge of three factors: (1) the habits of the respondents, (2) the type of house in which they lived and worked, (3) the diseases they suffered. We also administered them a hospital anxiety and depression scale questionnaire. A statistical analysis was performed calculating the $p$ value and a Yates chi square test to compare the percentages of diseases that emerged in three different groups: (1) the sample, (2) an ISTAT report on women of the same average age performing various work tasks 'other than housework' and (3) an ISTAT nationwide report on the housewives of the same average age. Finally, we evaluated the average questionnaire scores measuring anxiety and depression, and correlated those scores with age.

Results: the sample group consisting of 468 housewives showed high percentage of allergic disorders (35.6\%), which is statistically significant when compared to the ISTAT national data on women generally and housewives particularly of the same average age. The evaluation of data on anxiety and depression showed an average score indicating borderline
\end{abstract}

pathology for both (anxiety and depression) and increasing proportionally with increasing age.

Discussion: it is considered appropriate to inform society and the scientific community about the issues concerning these housewife workers, who must be regarded as and recognized as workers.

KEY WORDS: housewives, home risk exposure, diseases, accidents.

\section{Introduction}

The deep and rapid economic and social changes that occurred over the last 60 years in Western Society have also changed the characteristics of our Country. Up to the beginning of the twentieth century, our economy was based on agricultural. Subsequently, with the industrial transformation of the economy especially after World War II, there was a progressive development of the tertiary services. In 2001 in Italy $5.2 \%$ of workers were employed in agriculture, $31.7 \%$ in industry and $63.1 \%$ in the services sector. In the third quarter of 2015 , there were 815,000 people employed in agriculture (3.6\%), in industry $6,034,000(26.9 \%)$ and in the services sector $15,648,000(69.5 \%)(1,2)$.

Therefore, the indoor work (e.g. service) is prevalent today, but much neglected until the mid-70s and considered no more dangerous to workers' health than other sectors, has increasingly become the subject of scientific interest.

The number employed in the services sector would be even greater if it included all those who carry out work activities related to the care of their homes. This population has never been considered productive, in as much as such activities are carried out free of charge (i.e. not compensated with payroll wages) (3). At the beginning of the '90s, the number of housewives in Italy was estimated at 9.805 million, while in 2013 there were 7.562 million with a decrease of $22.8 \%$ in recent years $(4,5)$. The analysis of injury and risk factors related to this sector shows that employee exposure to pathogenic noxae of various kinds is even higher than that of other traditional indoor working environments such as offices. Just consider for example detergents products used in washing, cleaning, and the maintenance of the house; disinfectants and pesticides; or various combustible products which are formed during the preparation of meals. See Table 1 for a list of some such pathogenic products found in the home (6).

Besides the risk of pollutants in the home there are also conditions for injury, which statistics clearly show common. Based on approximate measures, it seems that in Italy, during the first half of the '90s, domestic accidents 
Occupational exposure to home risk factors: analysis of physical and mental health condition of a group of Sicilian housewives

Table 1 - Main sources of pollutants at home.

\begin{tabular}{ll}
\hline Source of pollution & Causative agents \\
\hline Building materials & radon, asbestos, mineral fibers \\
Covering materials (carpets, tapestries) & $\begin{array}{l}\text { volatile organic compounds, biological contaminants } \\
\text { formaldehyde, volatile organic compounds }\end{array}$ \\
Furniture & pentachlorophenol, other pesticides, fungicides, solvents \\
Wood paneling & asbestos, mineral fibers, volatile organic compounds \\
Insulation materials & gas (NOx, SOx, CO, O3), polycyclic hydrocarbons \\
Apparatus for combustion (gas stoves, heaters) & volatile organic compounds, fluorocarbons, solvents \\
Cleaning products (spray) & bacteria, fungi, viruses \\
Conditioning systems & bacteria, fungi, viruses, pollen, organic droppings, pesticides \\
People, pets, plants & gas, polycyclic hydrocarbons, respirable particles, volatile organic \\
Cigarette smoke & $\begin{array}{l}\text { compounds } \\
\text { chlorine, radon, volatile organic compounds }\end{array}$ \\
Water (faucets, showers ...) & particles, gases, biological contaminants, pesticides \\
Outdoor air &
\end{tabular}

amounted to more than a million per year, of which between 4,500 and 6,500 were fatal (especially due to fire), i.e. three times the number of deaths from accidents in the workplace (7).

The ISTAT data in 1999 reported 3,000,000 domestic accidents in which women were the most affected: the ratio of women's injuries to men's was 3:1.

In 2006, ISTAT reported 3,200,000 domestic accidents (64\% in women and $36 \%$ in men), highlighting serious and widespread phenomenon which still must be exactly interpreted, because not all occurred in housewives during their work, but in all the inhabitants of the house (8). In 1999 in Italy a law was approved making it compulsory to take out an insurance policy for all housewives between the ages of 18 and 65, including male subjects who perform domestic work in their own (9). Given the increased sensitivity to the problem of 'working-athome', in recent years there has been a reduction of accidents in the home for housewives. The latest INAIL data on accidents reported in the 'working-at-home' occupational category, showed a downward trend with a reduction of $57.4 \%$ in the period $2010-2014$ (10) (Tab. 2). We have no data on possible occupational diseases in this category, and there aren't sufficient studies around the world that will give us a rough estimate. Also, there is little information about problems associated with exposures to certain home risk factors.

The purpose of this study is to present an analysis of the possible environmental risk factors associated with physical and mental health in a sample group of Sicilian housewives, noting the epidemiology of diseases linked to the performance of their work activities at home.

\section{Materials and Methods}

We enrolled housewives born and living in Palermo and Catania. The women were given an anonymous questionnaire seeking information about their habits and the type of house in which they operated, in order to estimate the prevalence of possible diseases correlated with exposure to risk factors present in the home. Questions were asked about: the length of employment, smoking habits, presence of domestic workers at home, the type of detergents used, working times (hours and days), accompaniment of children, social activities, presence of pets, use of pesticides for plants, use of computers and the ability to drive cars. We also investigated the conformity of electrical systems with European regulations EEC, the type of heating, the presence and approximate purchase date of some appliances, the number of rooms and windows in the house, and existence in the building of an elevator. We asked even what activities (for example cleaning floors or during the preparation of meals) were performed during occurred accidents (burns, fractures, explosions, fires) and if they was affected by major diseases, such as: hypertension, diabetes, cardiovascular diseases, allergopathies, arthrosis, slipped disc, respiratory diseases and so on, with particular emphasis on allergic diseases and spinal

Table 2 - Trend of accidents reported by housewives in the period 2010-2014 (source INAIL).

\begin{tabular}{|c|c|c|c|c|c|}
\hline Year & 2010 & 2011 & 2012 & 2013 & 2014 \\
\hline Number of injuries reported & 1489 & 1166 & 1047 & 915 & 634 \\
\hline Percent reduction from the previous year & & $-21,7 \%$ & $-10,3 \%$ & $-12.6 \%$ & $-30,7 \%$ \\
\hline
\end{tabular}


injuries associated with heavy lifting.

The survey population was also administered a validated questionnaire: "Hospital anxiety and depression scale test", to estimate the presence of anxiety and/or depression. There were 14 questions, (7 anxiety measures and 7 depression) with a scores scale of 0 to 21 for each condition (anxiety and depression). Every question could obtain a score from 0 to 3 . This scale is a measure of the severity of the anxiety and depression experienced by the respondent - see Figure 1 below $(11,12)$. A statistical analysis was performed to compare the percentages of physical diseases reported in the sample with those obtained by ISTAT on women of the same average age, performing various work tasks. The percentages of diseases reported by the survey sample were also compared with those of housewives of the same average age nationwide. We calculated in both cases the $p$ value and the chi-square test according to Yates. We also examined the average level of anxiety and depression, on the basis of the findings of the questionnaire Hospital anxiety and depression scales.

\section{Results}

The sample consisted of 468 subjects, all female housewives with an age between 19 and 86 years; the aver- age number of children for each women was 2.4. The general characteristics of the sample population are described in Table 3.

Among the women recruited for the study 112 (23.9\%) worked previously in other activities: 55 were administrative employees $(11.8 \%), 37$ teachers $(7.9 \%), 11$ contractors $(2.3 \%)$, traders $5(1.1 \%), 4$ dressmakers $(0.9 \%)$. Table 4 summarizes the housewives' habits and type of work done in the home. In the total sample 111 were smokers (23.7\%).

The physical and mechanical characteristics of homes are shown in Table 5.

One hundred and sixty four housewives in the group $(35 \%)$ reported having suffered significant injuries in the home, but only 79 subjects $(16.8 \%)$ were precise: 70 cases $(14.9 \%)$ reported suffering fractures in upper and lower limbs and 9 head injuries (1,9\%). Also, one house experienced an explosion. There were no noteworthy injuries from fires or electrocutions.

The main diseases reported in the sample are shown in Table 6, where they are compared with the ISTAT statistical data on 'All women in Italy' of the same average age and with women of the same average age performing the job of housewives.

Specifically, in the sample, allergopathies found in 167 cases (35.6\%) are as follows: 69 cases of rhinitis $(14.7 \%$ of the total of the sample), 39 of conjunctivitis

Table 3 - Composition of the sample.

\begin{tabular}{|c|c|c|c|c|}
\hline $\begin{array}{l}\text { Number of housewives } \\
\text { in the sample }\end{array}$ & Age (mean $\pm \mathrm{DS})$ & $\begin{array}{l}\text { Seniority in years } \\
\text { (mean } \pm \text { DS) }\end{array}$ & $\begin{array}{l}\text { Hours of work in } \\
\text { a day (mean } \pm \text { DS) }\end{array}$ & $\begin{array}{l}\text { Number of house- } \\
\text { wives with previous } \\
\text { different work }\end{array}$ \\
\hline $468(100 \%)$ & $51 \pm 13.7$ & $24.1 \pm 15.2$ & $8.2 \pm 2.5$ & $112(23.9 \%)$ \\
\hline
\end{tabular}

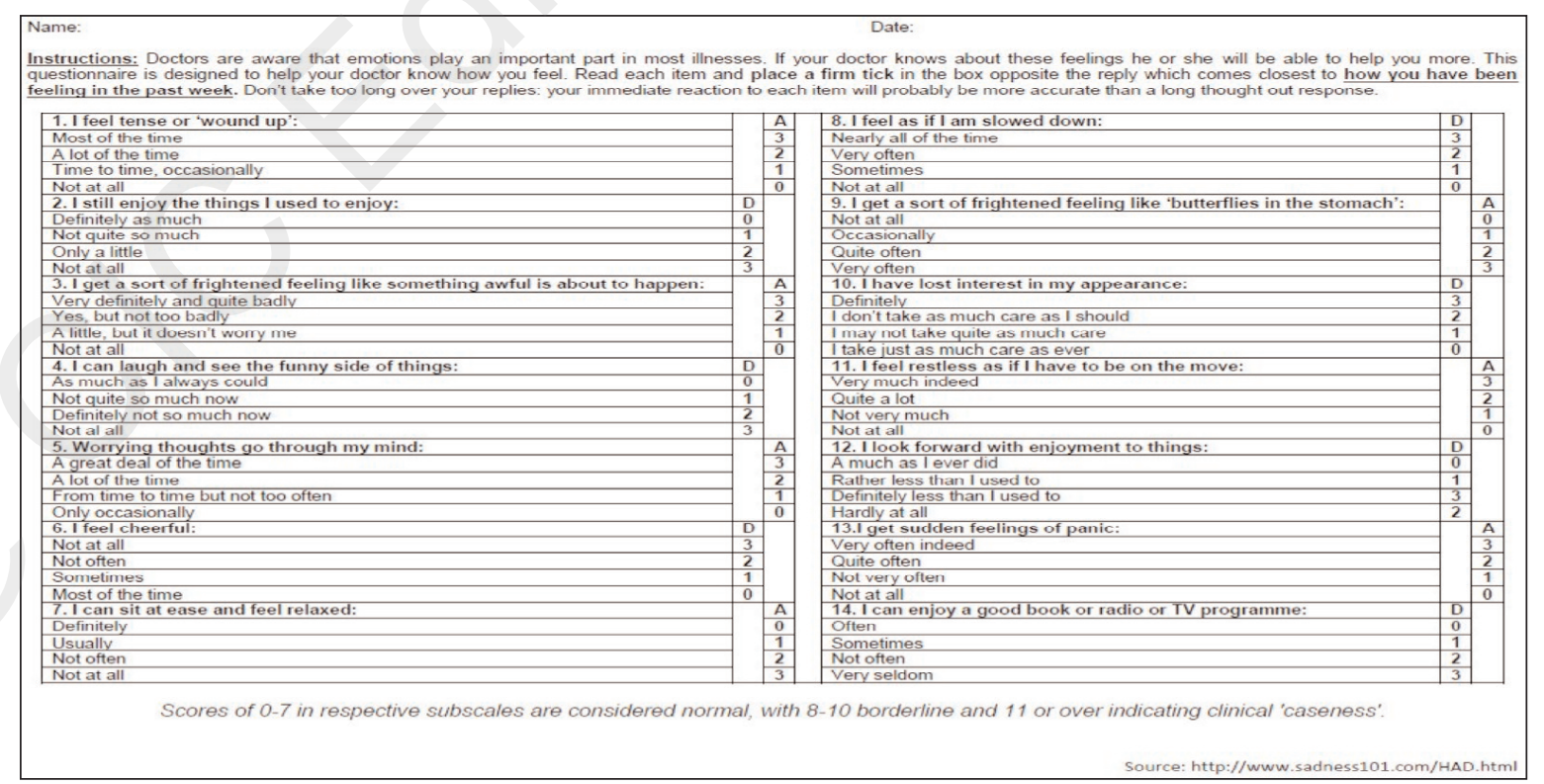

Figure 1- Hospital anxiety and depression scale test. 
Occupational exposure to home risk factors: analysis of physical and mental health condition of a group of Sicilian housewives

Table 4 - Habits and occupational exposures in the home number and percentage of subjects.

\begin{tabular}{ll}
\hline Investigated characteristic & Number of subjects and percentage \\
\hline With domestic workers & $120(25.6 \%)$ \\
Pets at home & $153(32.6 \%)$ \\
Users of pesticides for plants & $251(53.6 \%)$ \\
Users of detergents (especially bleach and ammonia) & $421(89.9 \%)$ \\
Hand washing & $436(93.1 \%)$ \\
Cleaning the house and cook & $449(95.9 \%)$ \\
Owners of washing machine & $468(100 \%)$ \\
Owners of vacuum cleaners & $419(89.5 \%)$ \\
Owners of dishwashers & $227(48.5 \%)$ \\
Owners of microwave oven & $208(44.4 \%)$ \\
\hline
\end{tabular}

Table 5 - Physical and mechanical characteristics of homes.

\begin{tabular}{ll}
\hline Investigated house characteristics & Number of owners subjects and percentage \\
\hline Electrical system according to law & $392(83.7 \%)$ \\
Average number of rooms & 4.5 \\
Average number of windows & 6.5 \\
Presence of elevator in the building & $415(88.7 \%)$ \\
Autonomous heating (radiators) & $152(32.4 \%)$ \\
Central heating & $123(26.2 \%)$ \\
Air conditioner to use to heat & $71(15.1 \%)$ \\
Fireplace & $23(4.9 \%)$ \\
No type of heating & $99(21.1 \%)$ \\
\hline
\end{tabular}

(8.3\%), 20 of urticaria (4.2\%), 17 of asthma (3.6\%), and finally 22 of atopic dermatitis $(4.7 \%)$, percentages with results comparable to other studies carried out in the past in dermatology (13).

In the group of sample housewives with osteoarthrosis, 23 reported herniated discs ( $4.9 \%$ of the total sample) detected with CT and MRI, while the other 36 have reported arthrosis in multiple location (7.7\%) uncomplicated by disk disease. Among the women with heart diseases, 11 reported a previous myocardial infarction $(2.3 \%$ of the total sample), 2 had a Wolff-Parkinson-White syndrome $(0.4 \%)$, 1 had a pacemaker $(0.2 \%)$. Other diseases reported were found in very few cases and not representative, therefore not an object of interest.

Analyzing the results shown in Table 6, we can see that in our sample there is a statistically significant difference of number of allergies compared to the other groups, in the sense of a greater number of cases. Instead Sicilian housewives, regarding the prevalence of diseases such as diabetes, hypertension and osteoarthrosis, show similar prevalences to Italian women of the same average age performing other jobs, and very different from those of the Italian housewives, which showed values much higher than the other two groups.

Survey questions were meant to generate psychological profiles; assessing 'anxiety and depression', and 'behavioral habits'. Table 7 summaries the behavioral habits.

As noted above, survey questions pertaining to psychological profiles used a numerical scaling method for measuring the degree of anxiety and depression suffered by the women. The scoring range from 0 to 21 is directly proportional to the severity of the condition: $0-7$ is considered normal, 8-10 borderline and 11-21 pathological.

The analysis of the data found a total average value of 10.11 (DS 4,16) for anxiety and 7.35 (SD 4.24) for depression. Further, dividing the test subjects by age shows that there are slightly lower values in younger women, under the age of 50 . Their average anxiety score was 9,71 (DS 4.14), and 6.38 for depression (SD 4.27). For the women over fifty: an average anxiety score of 10.4 (SD 4.18) and average depression score 8.05 (SD 4.11) (see Figure 2).

In only a few cases there was a prevalence of depression. For example, a fairly unique case of a twenty-five year old woman who had a very high level of anxiety and depression with respective scores of 18 and 16 . Other studies conducted in other countries confirm the results we have obtained $(14,15)$. 
Table 6 - Percentage of diseases found in the sample in comparison with national data on women in general (age 45-54 years) and with national data on housewives (age 45-54 years). The statistically significant differences are highlighted in bold. Source: ISTAT.

\begin{tabular}{|c|c|c|c|c|c|c|}
\hline & & Hypertension & Diabetes & $\begin{array}{l}\text { Cardiovascular } \\
\text { diseases }\end{array}$ & $\begin{array}{l}\text { Allergic } \\
\text { diseases }\end{array}$ & Arthrosis \\
\hline Sample in exam & & $\begin{array}{l}\text { n. } 25 \\
(5.3 \%)\end{array}$ & $\begin{array}{l}\text { n. } 12 \\
(2.5 \%)\end{array}$ & $\begin{array}{l}\text { n. } 14 \\
(3 \%)\end{array}$ & $\begin{array}{l}\text { n. } 167 \\
(35,7 \%)\end{array}$ & $\begin{array}{l}\text { n. } 59 \\
(12,6 \%)\end{array}$ \\
\hline All women in Italy (45-54 years) & & $11.6 \%$ & $2.2 \%$ & $1.3 \%$ & $13.3 \%$ & $15.8 \%$ \\
\hline Housewives in Italy (45-54 years) & & $30 \%$ & $10.5 \%$ & $5.6 \%$ & $9.9 \%$ & $34.2 \%$ \\
\hline $\begin{array}{l}\text { Sample in exam versus all women } \\
\text { in Italy ( } 45-54 \text { years) }\end{array}$ & $\begin{array}{l}\mathrm{p} \text { value } \\
\text { OR }\end{array}$ & $\begin{array}{l}0.17 \\
0.43\end{array}$ & $\begin{array}{l}0.74 \\
1.4\end{array}$ & $\begin{array}{l}0.73 \\
2.35\end{array}$ & $\begin{array}{l}0.0004 \\
3.62\end{array}$ & $\begin{array}{l}0.65 \\
0.77\end{array}$ \\
\hline $\begin{array}{l}\text { Sample in exam versus } \\
\text { housewives in Italy ( } 45-54 \text { years) }\end{array}$ & $\begin{array}{l}\mathrm{p} \text { value } \\
\text { OR }\end{array}$ & $\begin{array}{l}0 \\
0.13\end{array}$ & $\begin{array}{l}0.04 \\
0.22\end{array}$ & $\begin{array}{l}0,57 \\
0.52\end{array}$ & $\begin{array}{l}0 \\
5.05\end{array}$ & $\begin{array}{l}0.0006 \\
0.28\end{array}$ \\
\hline $\begin{array}{l}\text { Housewives in Italy ( } 45-54 \text { years) } \\
\text { versus all women in Italy ( } 45-54 \text { years) }\end{array}$ & $\begin{array}{l}\mathrm{p} \text { value } \\
\text { OR }\end{array}$ & $\begin{array}{l}0.0024 \\
3.27\end{array}$ & $\begin{array}{l}0.0343 \\
5.22\end{array}$ & $\begin{array}{l}0.2011 \\
4.5\end{array}$ & $\begin{array}{l}0.5961 \\
0.72\end{array}$ & $\begin{array}{l}0.0045 \\
2.77\end{array}$ \\
\hline
\end{tabular}

Table 7 - Investigated habits to evaluate the psychological profiles.

\begin{tabular}{ll}
\hline Investigated habit & Number of subjects and percentage \\
\hline With driving license & $340(72.6 \%)$ \\
Using computer & $91(19.4 \%)$ \\
Practitioners hobby & $161(34.4 \%)$ \\
Associating with old friendships (started before the wedding) & $187(39.9 \%)$ \\
Associating new friends (started after marriage) & $291(62.1 \%)$ \\
Makes coffee just for herself & $143(30.5 \%)$ \\
Alcohol consumption between meals & $72(15.4 \%)$ \\
\hline
\end{tabular}

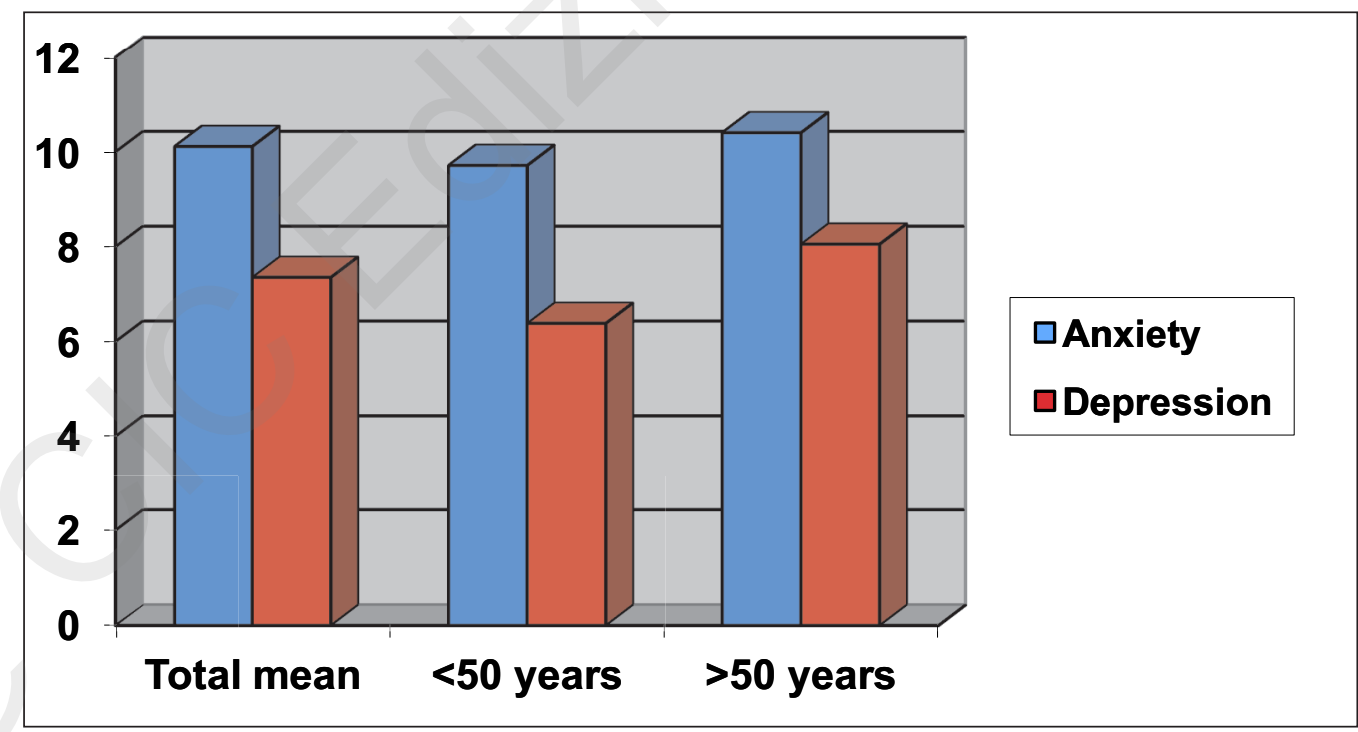

Figure 2 - Average values of score found in the evaluation of test anxiety and depression.

\section{Discussion}

Given the small size of the survey sample, no generalizations about the housewife population may be logical- ly inferred. However, what can be said is that the worker category of 'housewives' was and still is in many ways neglected and denied professional dignity. Also importantly, there is a significant disregard to home 'work- 
place' exposure to risks of various kinds: chemical, physical, biological, psychological and especially accident. The international scientific communities lack of interest in housewife habits and epidemiology is demonstrated by the paucity of professional literature on the subjects. This lack of interest is a result of the tendency to consider work done at home as 'non-work' because it is not compensated by payroll wages.

Further, given the observed epidemiology of the survey sample, it seems appropriate to differentiate the diseases not attributable to the work duties performed and those diseases that can sometimes have negative effects on the lives and the work of housewives. The finding of allergopathies in over $35 \%$ of the subjects evaluated and $35 \%$ accidents is indicative of the health significance of working in the home environment. Although, as noted, the small number of test subjects can not serve as a basis to infer definitive conclusions.

Another important point to emphasize is the pathology of the psychic sphere: the measurement of anxiety and depression increased with age, and the importance of $15 \%$ of housewives dedicated to alcohol consumption between meals, should lead us to consider the condition of these people who, for the lack of job satisfaction, for the lack of recognition of the work done and at the same time for daily tasks and responsibilities towards the family, more than others may experience symptomatic expressions of depression and/or anxiety.

Comparing national data of housewives with average age of those in our sample (45-54 years) with those of women of the same age in Italy, the numbers indicate that housewives in Italy are more at risk of high blood pressure, diabetes mellitus and osteoarthrosis than women performing others works. Data that does not however apply for housewives Sicilian, perhaps for the adoption of appropriate lifestyles, such as perhaps, the Mediterranean diet.

In sum: the variety of risk factors and diseases caused by exposure to pollutants is considered appropriate research in the various branches of medicine and in particular the Occupational Medicine, where such research is considered of the highest importance. Research into the occupational hazards of working-at-home seeks knowledge of epidemiology, and proposing remedies and precautions in order to prevent physical and mental illnesses and injuries, just as it does for all other categories of workers.

All this should be part of a program of training of and providing information to housewives about work-athome risks and also involving INAIL on topics other than work-related injuries, as already happens in the busi- ness world. More sensitivity about these are needed, especially now that women/housewives are more emancipated and educated on average than in the past, and consider themselves workers who want to be recognized as workers.

\section{References}

1. Istat. (2011). II mercato del lavoro italiano: un confronto europeo. Avalaible from: ww.istat.it/it/files/2011/02/3dossier3.doc

2. Istat. (2015). Occupati per settore di attività economica. Avalaible from: http://www.istat.it/it/lavoro

3. Urbano ML. II lavoro femminile. In Ambrosi L, Foà V.: Trattato di Medicina del Lavoro. UTET, Torino, 1996.

4. Melino C, D'Andrea R. II lavoro femminile. In Melino C: Lineamenti di lgiene del Lavoro. SEU, Roma, 1992.

5. Ansa. (2014). Italia ancora Paese di casalinghe, sono 7,5 milioni. Avalaible from: http://www.ansa.it/web/notizie/ rubriche/economia/2014/03/07/Italia-ancora-Paese-casalinghe-sono-7-5-milioni_10198042.html

6. Picciotto D, De Marchis P, Verso MG. Lavoro Domestico. In: Alessio L, Franco G, Tomei F: Trattato di Medicina del Lavoro. Piccin editore, Padova, 2015.

7. Figà-Talamanca I, Berlinguer G. II lavoro femminile. In Casula $D$ et al. Medicina del Lavoro. Monduzzi editore, Bologna, 1996.

8. Inail. (2012). Infortuni Domestici: epidemiologia del fenomeno ed approfondimenti sulla popolazione infortunata. Avalaible from: http://www.salute.gov.it/imgs/C_17_pubblicazioni_1851_allegato.pdf

9. Legge n. 493 del 03/12/1999: Norme per la tutela della salute nelle abitazioni e istituzione dell'assicurazione contro gli infortuni domestici. Gazzetta Ufficiale Repubblica Italiana N. 303 del 28/12/1999.

10. INAIL. (2015). Infortuni sul lavoro - Denunciati - Casalinghe. Avalaible from: http://bancadaticsa.inail.it/bancadaticsa/bancastatistica.asp? cod $=2$

11. Zigmond AS, Snaith RP. The hospital anxiety and depression scale. Acta Psychiatrica Scandinavica. 1983; 67(6): 361-370.

12. Zigmond AS, Snaith RP. The hospital anxiety and depression scale. Avalaible from: https://hotfudgesundaes.wordpress.com/tag/hads/

13. Lodi A, Mancini LL, Ambonati M, et al. Epidemiology of occupational contact dermatitis in a North Italian population. Eur J Dermatol. 2000; 10(2):128-132.

14. Carta MG, Carpiniello B, Dazzan P, Reda MA. Depressive symptoms and occupational role among female groups: a research in a south-east African village. Psycopathology. 2000; 33(5):240-245.

15. Khlat M, Sermet C, Le Pape A. Women's health in relation with their family and work roles: France in the early 1990 s. Soc Sci Med. 2000; 50(12):1807-1825. 